\title{
World Bank의 對파키스탄 경제원조
}

1. 세계은행 Paul D. Wolfowitz 총재는 8월 15일 17일간 파키스탄을 방문하여 Musharraf 대통령, S. Aziz 총리 및 수전력청장 등 주요인사와 면담, 파 키스탄의 경제성장이 궤도에 진입하였음을 평가하면 서 지속성장과 경제성장 과실의 공평한 분배가 향후 파키스탄 정치사회 안정의 관건임을 강조하고, 파키 스탄의 경제성장 노력을 지원하기 위해 각종 인프라 개발, 빈곤퇴치분야 등의 분야에 향후 수년간 매년 약 15 억불을 지원해 나가겠다고 약속함.

2. S. Aziz 총리 등은 Wolfowitz 총재 면담 계기에 (1)지난 60 년대 WB가 인더스강 유역문제를 둘러싼 파키스탄 · 인도간 문제를 원만히 해결하여 양국간 관계안정에 크게 기여한 사실을 상기하면서 $\mathrm{WB}$ 가 '제2의 Indus Initiative' 를 통해 인더스강 유역 개발 을 주도하여 이를 통해 파키스탄 - 인도간 이해관계 를 적극적으로 조정해 달라고 요망하는 한편, (2)파 키스탄 경제의 지속성장에 불가결한 에너지 수급문
제 등 사회인프라 개발을 위해 향후 15 년간 약 100 억 불 정도의 원조를 $\mathrm{WB}$ 에 요청함.

Jatoi 수전력청 장관은 경제성장에 따른 에너지 수요증대에 대응하기 위해 인더스강 유역에 수십 억불 규모의 댐(Bashar댐, Kalabah댐 Project)과 중소 규모 다목적댐 건설계획을 제시하면서 $\mathrm{WB}$ 의 원조를 요청

Hafeez 회계감사원장은 파키스탄이 돈세탁방지 법 등 국제적인 불법자금유출 방지 체제를 정비 중 임을 설명하면서 파키스탄으로부터 불법 유출된 자금을 회수하는데 $\mathrm{WB}$ 의 지원을 요청

[자료:주파키스탄 대사관] 